Schmidt et al. Knickpoint Evolution on the Yarlung River: Evidence for late Cenozoic Uplift of the Southeastern Tibetan Plateau Margin

\title{
Knickpoint Evolution on the Yarlung River: Evidence for late Cenozoic Uplift of the Southeastern Tibetan Plateau Margin
}

\author{
Jennifer L Schmidt ${ }^{1}$, Peter K Zeitler $^{1}$, Frank J Pazzaglia ${ }^{1}$, Marissa M Tremblay ${ }^{2,3}$, David L Shuster ${ }^{2,3}$, \\ Matthew Fox ${ }^{2,3}$ \\ ${ }^{1}$ Department of Earth and Environmental Sciences, Lehigh University, 1 W. Packer Ave., Bethlehem, PA \\ 18015, USA \\ ${ }^{2}$ Department of Earth and Planetary Science, University of California, Berkeley, 307 McCone Hall \#4767, \\ Berkeley, CA 94720-4767, USA \\ ${ }^{3}$ Berkeley Geochronology Center, 2455 Ridge Road, Berkeley, CA 94709, USA
}

*Corresponding author: jlm711@lehigh.edu 
Schmidt et al. Knickpoint Evolution on the Yarlung River: Evidence for late Cenozoic Uplift of the Southeastern Tibetan Plateau Margin

\section{Abstract}

2 A salient geomorphic feature of the Yarlung River is its abundance of large knickpoints, which in

3 many cases coincide with north-south trending rifts. Across one of these rifts, near the town of Jiacha, the

4 Yarlung falls nearly $500 \mathrm{~m}$ from an elevation of $\sim 3500 \mathrm{~m}$ over 80 river kilometers, making this the

5 second largest knickpoint on the river. We propose that the Jiacha knickpoint represents a wave of

6 incision migrating upstream through the drainage network in response to a downstream base level fall, not

7 a disturbance in the channel to due rift tectonics.

8 Longitudinal profile slope-area and chi $(\chi)$ analysis of Yarlung River tributaries and those of several

9 major rivers in southeastern Tibet indicate severalknickpoints are present at $\sim 3500$ m elevation,all

10 resulting from a single regional-scale base level fall. Retreat rates calculated from celerity modeling

11 indicate that the Jiacha knickpoint was located at the upstream edge of the Namche Barwa massif at $\sim 10$

$12 \mathrm{Ma}$, a history consistent with apatite ${ }^{4} \mathrm{He} /{ }^{3} \mathrm{He}$ thermochronometry data and thermokinematic modeling

13 from that region. These data suggest the Yarlung River has flowed in its present course through this area

14 since at least $10 \mathrm{Ma}$ and imply that at least500 $\mathrm{m}$ of incision occurred within this canyon over this time

15 period. The spatial scale of these observations suggests that these knickpoints resulted from surface uplift

16 of southeastern Tibet of 500 to $2500 \mathrm{~m}$ just prior to $10 \mathrm{Ma}$. Additionally, our mapped knickpoint

17 locations indicate that reorganization of the drainage network just east of the Namche Barwa massif

18 occurred prior to this time.

20 Keywords: Yarlung River; landscape evolution; knickpoint celerity modeling; ${ }^{4} \mathrm{He} /{ }^{3} \mathrm{He}$ apatite

21 thermochronology;thermokinematic modeling.

\section{1. Introduction}

24 The Yarlung River flows strike parallel to the Himalayan orogen for $\sim 1,700 \mathrm{~km}$ in southern Tibet

25 before it abruptly drops over an $\sim 2 \mathrm{~km}$ knickpoint and changes trajectory by $\sim 180^{\circ}$ in a gorge only 200

$26 \mathrm{~km}$ long in the eastern Himalayan syntaxis (Fig. 1). The river drains $>200,000 \mathrm{~km}^{2}$ of the Tibetan 
Schmidt et al. Knickpoint Evolution on the Yarlung River: Evidence for late Cenozoic Uplift of the Southeastern Tibetan Plateau Margin

27 plateauand delivers $2000 \mathrm{~m}^{3} / \mathrm{s}$ of discharge through the syntaxis (Montgomery et al., 2004), making the

28 Yarlung River one of the major drainage catchmentsin Tibet and the largest in the southern

29 plateauthrough which eroded sediments are evacuated. The topographic evolution of the southern Tibetan

30 landscape is thus largely controlled by the base level established onthe Yarlung drainage.

31 The longitudinal profile of the Yarlung River contains several large knickpoints, river reaches with

32 convex elevation profiles and anomalously steep slopes (Fig. 2A). In the eastern portion of the catchment,

33 near the town of Jiacha, the Yarlung channel navigates a narrow bedrock gorge, falling 500 $\mathrm{m}$ in

34 elevation over 80 river $\mathrm{km}$ from an elevation of $3500 \mathrm{~m}$ to form the second largest knickpoint on the river.

35 In a detachment-limited stream power model (Howard and Kerby, 1983; Howard et al., 1994; Whipple

36 and Tucker, 1999), in which elevation is increased due to rock uplift rate $(U)$ and lowered through erosion

$37\left(E=K A^{m} S^{n}:\right.$ where $A$ is upstream drainage area; $S$ is local along channel slope; $K$ is bedrock erodibility),

38 such deviations from a graded, concave-up profile in a long-lived river imply eitherspatial variations in

39 rock uplift rate or transience in the system associated with major changes in base level and upstream

40 migration of erosional waves. As with several other knickpoints on the Yarlung River, the Jiacha

41 knickpoint locally coincides with a late Cenozoic N-S trending rift that accommodates E-W extension in

42 southern Tibet (Kapp et al., 2008; Yin et al., 1999; Fig. 1). An obvious inference is that dynamic support

43 and/or active rift-flank uplift is locally steepening the Yarlung channel, forming the knickpoint (Zhang,

44 1998). However, the lack of major offset on this this rift (Yin et al. 2010) precludes pinning of the Jiacha

45 knickpoint to this location for an extended period of time. An alternative hypothesis that we test here is

46 that the Jiacha knickpoint formed as a result of a regional base level fall downstream of its present

47 position, propagating through the drainage network and triggering a wave of incision that is presently

48 carving through the eastern Jiacha rift flank. Knickpoints originating in this manner travel upstream witha

49 celerity of $K A^{m}$ (assuming $n=1$; Crosby and Whipple, 2006; Rosenbloom and Anderson, 1994; Weissel

50 and Seidl, 1998; Whipple and Tucker 1999; Whipple et al., 2000) and should be evidentin rivers

51 throughout the drainage network.Furthermore, solutions to the stream power model indicate that transient

52 features with a constant travel time $(\tau)$ should be present at the same elevation (Weissel and Seidl, 1998; 
Schmidt et al. Knickpoint Evolution on the Yarlung River: Evidence for late Cenozoic Uplift of the Southeastern Tibetan Plateau Margin

53 Pritchard, 2009; Royden and Perron, 2013; Goren et al, 2014). As there is no signature of $K$ within the

54 landscape, it is possible to calculate a $K$-independent travel time with units of length (Perron and Royden,

55 2013), termed $\chi$, where $\chi(x)=K A_{0}^{m} \tau(x)$. By this method, knickpoints are identified at a specific

56 elevation and corresponding $\chi$ value. These represent idealized scenarios and in reality, $U$ and $K$ can be

57 spatially and temporally variable due to complex tectonics or variations in lithology or climate,

58 respectfully. Nevertheless, this simplified stream power model provides a framework to assess the origin

59 of this knickpoint,its relationship to knickpoints of similar elevation in southeastern Tibet, and

60 implications for late Cenozoic drainage reorganization and landscape evolution.

61 We test these ideas through a combination of longitudinal profile and knickpoint celerity modeling,

$62{ }^{4} \mathrm{He} /{ }^{3} \mathrm{He}$ apatite thermochronometry, and thermokinematic modeling to constrain the Cenozoic incision

63 history of the Yarlung downstream of the Jiacha knickpoint. Our results provide new perspective on the

64 timing of river capture east of the eastern Himalayan syntaxis.We highlight the integration of knickpoint

65 mapping with ${ }^{4} \mathrm{He} /{ }^{3} \mathrm{He}$ apatite thermochronometry and thermokinematic modeling as a novel approach to

66 interpreting paleo-drainage patterns. Finally, we speculate on the origin of the Jiacha knickpoint by

67 examining river profiles throughout eastern Tibet.

\section{Identifying TransientFeatures in the Yarlung Drainage Network}

We analyzed longitudinal profiles of the Yarlung and its tributariesupstream of the Namche Barwa massif to document evidence for migration of the Jiacha knickpoint in the reach immediately downstream, where knickpoint preservation is most likely.We used a $30 \mathrm{~m}$ ASTER digital elevation model (DEM) of southern Tibet as our base data setdownloaded from the USGS Global Data Explorer

74 (gdex.cr.usgs.gov/gdex). Using ESRI ArcGIS software, we extracted longitudinal elevation and drainage

75 area profiles of the Yarlung and several of its tributaries, smoothing profiles using a loess filter in order to

76 decrease noise and highlight the general form of the profile.

77 As erosion rate in the stream power model is equal to $K A^{m} S^{n}$, assuming the river is in steady state,

78 erosion rate is equal to uplift rate $\left(U=K A^{m} S^{n}\right)$ and we can therefore gain insight into relative erosion rates 
Schmidt et al. Knickpoint Evolution on the Yarlung River: Evidence for late Cenozoic Uplift of the Southeastern Tibetan Plateau Margin

79 by analyzing the relationship between $S$ and $A$.This is achieved by rearranging this expression and

80 regressinglinear segments of the streams in $\log S-\log A$ space to provide a channel steepness index $\left(\mathrm{k}_{\mathrm{s}}=\right.$

$\left.81[\mathrm{U} / \mathrm{K}]^{1 / \mathrm{n}}\right)$ and concavity $(\theta=\mathrm{m} / \mathrm{n})$. This slope-area analysis objectively highlights knickpoints in the

82 profile (Hack, 1957; Kirby and Whipple, 2001; Snyder et al., 2000). We identified knickpoints where

83 there is a change in a linear array of values to negative concavity in $\log S-\log A$ space, i.e. where a

84 particular reach has a convex profile (Fig. 2B).

8537 notable knickpoints exist within the Yarlung and 18 of its tributaries in the reach between the

86 Namche Barwa massif and Jiacha knickpoint (Fig. 3). One of these knickpoints coincides with a mapped

87 lithologic boundary. Of the others, 13 occur at elevations of $3500 \pm \sim 150 \mathrm{~m}$, the approximate elevation of

88 the Jiacha knickpoint.The lithology of the tributaries north of the Yarlung is more variable than that of the

89 southern tributaries and those lacking knickpoints at $\sim 3500 \mathrm{~m}$ are focused in the north. This additional

90 lithologic variation likely stalled or enhanced headward migration of these northern knickpoints, affecting

91 their elevation. Cross-valley profiles from above and below the tributary knickpoints do not significantly

92 differ, indicatingthe common elevation of these features does not reflect a regional erosive process change

93 from fluvially dominated to glacially dominated at $\sim 3500$ m elevation. The morphology of this landscape

94 at or below this elevation is therefore not controlled by glacial erosion.

95 A strong correlation exists between drainage area upstream of these 13 knickpoints and their distance

96 from tributary confluence with the Yarlung (Fig. 4A). Since the celerity of knickpoint retreat in the stream

97 power model is proportional to the drainage area raised to the power of $m$, this drainage area dependence

98 on the horizontal distance a knickpoint will travel predicts this relationshipwhen knickpoints are the result

99 of a common base level fall (Berlin and Anderson, 2007; Goren et al., 2014; Harkins et al., 2007;

100 Niemann et al., 2001; Van der Beek and Bishop, 2003; Whipple and Tucker, 1999; Zaprowski et al.,

101 2001). We can further investigate this relationship by looking for commonalities across entire tributary

102 channels and not solely the knickpoints. To remove the dependence of drainage area and negate the need

103 to calculate slopes, as those derived from DEMs are prone to noise, we calculate $\chi$ - elevation profiles for

104 the Yarlung River and its tributaries (Perron and Royden, 2013). If the tributaries share a common base 
Schmidt et al. Knickpoint Evolution on the Yarlung River: Evidence for late Cenozoic Uplift of the Southeastern Tibetan Plateau Margin

105 level history they should overlap in $\chi$-elevation space. Divergence of the profiles may be due to spatial

106 variation in channel incision processes or non-uniform precipitation expressed in $K$ (Perron and Royden

107 2013). For the Yarlung and its tributaries, steps corresponding to knickpoints at $\sim 3500$ m elevation

108 exhibit significant overlap, suggesting that these knickpoints are the result of a single, downstream base

109 level fall. The dissimilarity in the overall morphology of the $\chi$-elevation profiles between the northern

110 and southern tributaries may result from a difference in hillslope and fluvial erosion processes arising

111 from aspect and/or rock type.

112 The profile in Figure 4B shown in green contains a knickpoint at $\sim 3500 \mathrm{~m}$, however has significantly

113 different $\chi$ values for a given elevation, likely due to recent capture by that tributary as suggested by its

114 anomalous morphology observable in the DEM (see Fig. 3 for tributary location). This indicates that a

115 substantial change in the drainage area occurred after the knickpoint migrated into the area, which

116 increased $\chi$ values along this tributary.It is important to note that the absolute $\chi$ values are insignificant

117 here given the uncertainty in the magnitude of the total elevation change across the Jiacha knickpoint (see

118 section 6.3). Placing time constraints on the age of these knickpoint and commonalities requires external

119 data and is discussed in section 3.

120 The detection of downstream knickpoints withinstreams east of the Namche Barwa massif,provides

121 possible tests for mechanisms for this base level fall. Longitudinal profiles from six tributaries in the

122 Siang River, along with the Yigong and Parlung rivers and 11 of their tributaries extracted from a $90 \mathrm{~m}$

123 SRTM DEM (downloaded from www.viewfinderpanoramas.org) highlightfourteen knickpoints occurring

124 at $3500 \pm 200 \mathrm{~m}$ (Fig. 3).Threeof these knickpoints are located in the Namche Barwa massif within

125 currently glaciatedvalleys.Longitudinal profiles from these tributaries thus do not reflect the valley

126 bottom profile, but rather a combination of the glacier surface at high elevations and the valley bottom at

127 lower elevations. They are therefore not related to the Jiacha knickpoint. Major rivers analyzed draining

128 the eastern plateau margin and the Himalaya including the Subansiri, Dibang, Lhuit, Irrawaddy, Salween,

129 Mekong, Yangtze, and Yalong (Fig. S1) also haveknickpoints at $\sim 3500 \mathrm{~m}$, with the exception of the Lhuit 
Schmidt et al. Knickpoint Evolution on the Yarlung River: Evidence for late Cenozoic Uplift of the Southeastern Tibetan Plateau Margin

130 (Fig. 3). We discuss the implications of common elevation knickpoints in drainage networks spanning

131 such a large area in Sections6.2 and 6.3.

\section{3. ${ }^{4} \mathrm{He} /{ }^{3} \mathrm{He}$ Apatite Thermochronometry}

The development of high-relief topography such as that observed within the Yarlung River valley will perturb shallow crustal isotherms and thus shape the thermal history of the valley (Mancktelow and

136 Grasemann, 1997; Braun, 2002). If a wave of sufficiently deep incision migrated headward along the

137 Yarlung River, bedrock downstream of Jiacha should record exhumation-related cooling associated with

138 passage of the knickpoint. Apatite ${ }^{4} \mathrm{He} /{ }^{3} \mathrm{He}$ thermochronometry constrains cooling histories through the

139 uppermost few km of the crust.Schildgen et al. (2010) and Shuster et al. (2011) have demonstrated the 140 potential of this method in identifying incision propagating through high-relief valleys. Here, we apply

141 the method to samples downstream of the Jiacha knickpoint.

142 Retention of radiogenic ${ }^{4} \mathrm{He}$, produced by alpha decay of $\mathrm{U}$, Th, and $\mathrm{Sm}$ begins below $\sim 85^{\circ} \mathrm{C}$ and is 143 complete by $\sim 30^{\circ} \mathrm{Cin}$ apatite, depending on the size, cooling path, and the $\mathrm{U}$, Th, and Smconcentrations

144 of a given apatite crystal (Flowers et al., 2009; Shuster et al., 2006). A bulk (U-Th)/He apatite age is 145 calculated from the total abundances of ${ }^{238} \mathrm{U},{ }^{232} \mathrm{Th},{ }^{147} \mathrm{Sm}$ and radiogenic ${ }^{4} \mathrm{He}$ in an apatite, and provides a 146 non-unique constraint on the timing and rate of cooling between these temperatures. $\mathrm{In}{ }^{4} \mathrm{He} /{ }^{3} \mathrm{He}$

147 thermochronometry, stepwise degassing analysis of a sample containing a uniform distribution of proton-

148 induced ${ }^{3} \mathrm{He}$ resolves the spatial distribution of ${ }^{4} \mathrm{He}$ within a crystal, which more restrictively constrains 149 an individual sample's thermal history (Shuster et al. 2004); the ${ }^{4} \mathrm{He}$ distribution and the (U-Th)/He age 150 can thus be used to exclude thermal histories that are permitted on the basis of the (U-Th)/He age alone.

151 Our topographic analysis predicts that background exhumation within the valley will be punctuated by

152 a period of rapid incision associated with knickpoint migration. If the knickpoint propagated upstream,

153 this transient pulse of incision will have migrated with time. Bedrock apatite (U-Th)/He ages

154 shouldtherefore correlate with downstream distance from the Jiacha knickpoint and ${ }^{4} \mathrm{He} /{ }^{3} \mathrm{He}$ modeled 155 thermal histories will provide constraints on the cooling rate. We applied these methods to two sample 
Schmidt et al. Knickpoint Evolution on the Yarlung River: Evidence for late Cenozoic Uplift of the Southeastern Tibetan Plateau Margin

156 sets collected within the Yarlung River valley to (1) ascertain the relationship between bedrock age and

157 distance along the river, and (2) use modeled thermal histories to determine if samples experienced a

158 pulse of rapid cooling.

159 We collected two groups of bedrock samples along the Yarlung River valley bottom (Table S1). The

160 first group was collected near the base of the Jiacha knickpoint, while the second group spans a 100

161 kmtransect beginning $200 \mathrm{~km}$ downstream from the lip of the Jiacha knickpoint (Fig. 5). Sample

162 collectionat river level maximizes the potential for recording knickpoint migration-induced incision, as

163 these samples would experience the greatest amount of exhumation from this process. For analysis, we

164 selected individual euhedral apatite grains free of visible inclusions and with a spherical equivalent radius

165 of at least 50 microns from each sample. Following methods described by Shuster et al. (2004), samples

166 were subjected to proton irradiation to produce a uniform distribution of ${ }^{3} \mathrm{He}$. The ${ }^{4} \mathrm{He} /{ }^{3} \mathrm{He}$ ratio

167 wasmeasured by mass spectrometry during sequential, stepwise degassing of individual crystals (Table

168 S2). The evolution of this ratio with cumulative ${ }^{3} \mathrm{He}$ release reflects the spatial distribution of ${ }^{4} \mathrm{He}$ within

169 each grain. In these cases, we calculate the (U-Th)/He age from the sum of the ${ }^{4} \mathrm{He}$ released in all steps,

170 and the U, Th,and Sm molar abundancesin the same grain, measured by isotope dilution. The finite

171 difference model described by Schildgen et al. (2010) was used to model cooling histories that predict the

172 (U-Th)/He age within one standard error. Histories that satisfy this criterion are scored based on their

173 misfit with the observed ${ }^{4} \mathrm{He} /{ }^{3} \mathrm{He}$ ratio evolution of these samples (Schildgen et al., 2010). Modeled

174 histories with mean squared error (normalized to mean ratio uncertainty) of $<1.5$ represent good fits to our

175 observed ratios (see Schildgen et al., 2010).

176 Figure 5 shows observed apatite ${ }^{4} \mathrm{He} /{ }^{3} \mathrm{He}$ data, modeled cooling histories, and sample locations with

177 respect to the Jiacha knickpoint (see Fig. S3 for overlaid thermal histories). Within the valley transect, (U-

$178 \mathrm{Th}) / \mathrm{He}$ ages are $8.8 \pm 0.88 \mathrm{Ma}$ at the farthest downstream location and young to $4.4 \pm 0.44 \mathrm{Ma} \sim 100 \mathrm{~km}$

179 upstream (Fig. $5 \& 6$ ), demonstrating that cooling of these samples occurred earlier downstream than

180 upstream. These data are consistent with a wave of cooling associated with incision propagating upstream

181 as predicted by our knickpoint model. Apatite (U-Th)/He ages from the base of the knickpoint cluster 
Schmidt et al. Knickpoint Evolution on the Yarlung River: Evidence for late Cenozoic Uplift of the Southeastern Tibetan Plateau Margin

182 around 5 Ma. Because of the proximity of these samples to the present-day Jiacha knickpoint, they would

183 have been far abovethe He partial retention zone (PRZ) when it migrated through this location.We

184 therefore interpret these apatite ages as having been set during pre-knickpoint background erosion.

185 Thermal histories consistent with the observed ${ }^{4} \mathrm{He} /{ }^{3} \mathrm{He}$ data for upstream samples ML01, ML06, and

186 ML18 (Fig. 5, Table S2) do not record a major change in cooling rate but do permit rapid cooling,

187 suggesting they were below or entering the PRZ when knickpoint migration occurred. Because these

188 histories do not record the onset of rapid cooling, we can constrain the timing of initiation of rapid

189 incision at their location only to at least $4 \mathrm{Ma}$. The samples farthest downstream from the Jiacha

190 knickpoint (ML19, and ML21) display a range of permissible model histories that is broad enough that

191 we cannot resolve if these samples experienced fast or slow cooling. However, rapid cooling related to

192 knickpoint migration by at least $8 \mathrm{Ma}$ is permissible. Collectively, our modeled cooling histories from the

193 valley transect samples constrain a time window (4 - 8 Ma) over which the samples cooled that young

194 with upstream distance, which is consistent with our model of knickpoint migration. Predicted knickpoint

195 migration rates from these data are $20-25 \mathrm{~km} / \mathrm{Ma}$.

196 In general, ${ }^{4} \mathrm{He} /{ }^{3} \mathrm{He}$ data from samples from the base of the knickpoint have uncertainties on the

197 individual heating steps that are too large to provide quantitative constraints. Two samples from this area

198 (LB12-ZD08 and LB12-ZD07) have lower uncertainties; nonetheless we are unable to distinguish

199 between fast and slow cooling historiesusing these data (Fig.S4). We therefore present mean ages for

200 theseknickpoint samples in Figure 5. Additionally, we conducted conventional single crystal apatite (U-

$201 \mathrm{Th}) / \mathrm{He}$ analyses, calculating the (U-Th)/He age from the total release of ${ }^{4} \mathrm{He}$ in a single step (Table S3).

$202 \mathrm{U}, \mathrm{Th}$, and Sm molar abundanceswere measured from the same grain by isotope dilution.These ages agree

203 with those determined by ${ }^{4} \mathrm{He} /{ }^{3} \mathrm{He}$ thermochronometry for each sample, supporting the trend of

204 decreasing age with distance upstream.

205

\section{4. Knickpoint Celerity Modeling}


Schmidt et al. Knickpoint Evolution on the Yarlung River: Evidence for late Cenozoic Uplift of the Southeastern Tibetan Plateau Margin

207 We applied the stream power based knickpoint migration model for the Jiacha knickpoint following 208 the general methodology of Berlin and Anderson (2007) to predict the knickpoint celerity and therefore 209 mean retreat rate of valley incision directly downstream of Jiacha.

210 We selected three, adjacent north-flowing tributaries directly downstream of the Jiacha that have 211 prominent knickpoints at $\sim 3500 \mathrm{~m}$ (Fig. 3).Knickpoint celerity modeling is best constrained by using a

212 large number of tributaries that experience instantaneous and coeval base level fall. The Yarlung drainage 213 network geometry makes it difficult satisfy this requirement. Furthermore, differences in rock type among 214 tributaries influence $K$ and differences in aspect influence watershed hydrology $(m)$, as observed in the $\chi$ 215 elevation plot (Fig. 4).For these reasons, solutions to the celerity model that combined north-flowing and 216 south-flowing tributaries resulted in very high residual values for the best-fitting $K$ and $m$. Although not 217 ideal, the three tributaries used to constrain the celerity model have little to no variation in rock type, are 218 of similar size and hypsometry, and are all confluent with the Yarlung at nearly the same location.

219 We assumed that these three tributaries experienced a base level fall resulting from Jiacha knickpoint 220 migration at the exact same time, which is reasonable given the proximity of the tributary mouths where 221 they join the Yarlung and the rapid migration rate expected. We modeled $m$ and $K$ values assuming the 222 three tributary knickpoints initiated at 4.4 Ma $(t)$ based on the tributary locations and our interpretation of 223 sample ML01, the closest sample affected by knickpoint-related cooling. The distance from a tributary 224 mouth to the top of the 3500m elevation knickpoint $(x)$ and the corresponding upstream drainage area for 225 a tributary channel reach $(A)$ are known.

226 Using the celerity equation, we calculate a travel time through each cell of the tributary and 227 cumulatively step upstream through the profile until thetotal distanceis equal to the knickpoint travel 228 distance, $x$. The difference between the calculated travel times through that distance and the initiation time 229 (4.4 Ma) is the resulting misfit. The two-parameter exhaustive search approach applied searches 230 parameter space linearly for values of $m$ between 0.1 and 1.0 and logarithmically for $K$ between $10^{-4}$ and $231 \quad 10^{-12}$, to identify the best combination of $m$ and $K$ that minimizes the misfit among the three tributaries 
Schmidt et al. Knickpoint Evolution on the Yarlung River: Evidence for late Cenozoic Uplift of the Southeastern Tibetan Plateau Margin

232 (Berlin and Anderson, 2007; Crosby and Whipple, 2006). The residual-minimized $m$ and $K$ for these 233 tributaries are 0.42 and $9.33 \times 10^{-7} \mathrm{~m}^{-0.16} \mathrm{yr}^{-1}$ respectively.

234 We applied these best-fit values of $m$ and Kusing the celerity equationin a forward sense to the

235 Yarlung main channel to predict the location of the Jiacha knickpoint as a function of time. The Jiacha

236 knickpoint projects back in time to the base of the three modeled tributaries (Fig. 3) at 4.4 Ma which is

237 consistent with the notion that the tributary knickpoints were formed by migration of the Jiacha

238 knickpoint. Following the same approach, the Jiacha knickpoint projectsjust upstream of the Namche

239 Barwa massif at 10Ma (Fig. 3) and migrated at an average rate of $\sim 40 \mathrm{~km} / \mathrm{Ma}$.

\section{Thermokinematic Modeling}

Our bulk apatite ages, ${ }^{4} \mathrm{He} /{ }^{3} \mathrm{He}$-based thermal histories, and celerity modeling suggest that a wave of

243 incision migrated through the Yarlung River valley from the Namche Barwa massif starting at $~ 10$ Ma.

244 We use a forward 3D thermokinematic model to evaluate geologically plausible incision scenarios

245 consistent with our observed apatite (U-Th)/He data (using a modified version of Pecube; Braun, 2003).

246 For a prescribed model of topographic evolution, the model solves the heat transport equation through

247 time incorporating variable kinematic parameters to predict time-temperature history of each node in a 3-

248 dimensional grid.

249 Models of canyon incision require integrating both vertical background surface erosion and the

250 development of topography through time. As an initial condition of the model, we create a simplified

251 topography to simulate a flat surface cut by a $1.5 \mathrm{~km}$ deep valley with an $80 \mathrm{~km}$ long knickpoint (Fig. S5).

252 With successive time steps, the knickpoint advances horizontally upstream to cut the valley to a total of 2

$253 \mathrm{~km}$ deep. The background erosion rate, and its variance through time, is a prescribed parameter in our

254 model, as are knickpoint migration rate and geothermal gradient.We explored the effects of broadly

255 varying each parameter on the time-temperature history of the downstream canyon. Prescribed knickpoint

256 retreat rates dictate the model run times and wevaried these between $15-35 \mathrm{~km} / \mathrm{Ma}$. We assigned typical

257 geothermal gradientsof either $25^{\circ} \mathrm{C} / \mathrm{km}$ or $30^{\circ} \mathrm{C} / \mathrm{km}$. High-elevation (U-Th)/He apatite ages from near the 
Schmidt et al. Knickpoint Evolution on the Yarlung River: Evidence for late Cenozoic Uplift of the Southeastern Tibetan Plateau Margin

258 Yarlung-Nyang confluence indicate background exhumation rates are on the order of $0.25 \mathrm{~km} / \mathrm{Ma}$ (Zeitler 259 et al. 2014). However, we explored an order of magnitude variation in background erosion rates possible 260 in this region by assigning itto be either $0.01 \mathrm{~km} / \mathrm{Ma}$ or $0.25-0.2 \mathrm{~km} / \mathrm{Ma}$.

$261 \quad$ For each model run, we extracted time-temperature paths for nodes downstream of the ending

262 knickpoint location that correspond to our sample location distance from the Jiacha knickpoint. We then 263 useHeFTy (Ketcham, 2005) to predictapatite (U-Th)/He ages for the t-T paths of each of the five sample

264 nodes, assuming ${ }^{4} \mathrm{He}$ diffusion kinetics prescribed by the radiation damage accumulation and annealing

265 model (RDAAM; Flowers et al., 2009). We then calculated the sum of squared residuals between the

266 predicted and observed (U-Th)/He ages for each model run, and use its minimum toidentify the

267 bestfittingof the explored Pecube models (Table S4).

268 We find that a knickpoint retreat rate of $30 \mathrm{~km} / \mathrm{Ma}$ succeeds in predicting the youngest (U-Th)/He ages

269 and an increasing trend with downstream distance (Fig. 6), assuming a geothermal gradient of $25^{\circ} \mathrm{C} / \mathrm{km}$

270 and a continuous background exhumation rate of $0.2 \mathrm{~km} / \mathrm{Ma}$. Models with much faster rates of retreat

271 predict apatite (U-Th)/He ages far less than those observed and those with prescribed background erosion

272 rates an order of magnitude slower predict (U-Th)/He ages that are far older.

273

\section{6. Discussion}

275 Our results indicate that the geomorphic evolution of the Yarlung River and therefore erosion in 276 southern Tibet between the Namche Barwa Massif and the Jiacha knickpointhas been influencedby a 277 downstream base level fall in the Late Miocene. Furthermore, our data provide insights into the evolution 278 of the drainage network surrounding the eastern Himalayan Syntaxis. Finally, we examine major river 279 profiles in eastern Tibet to explore proposed river capture models for this region and speculate on the 280 origin of the Jiacha knickpoint. 
Schmidt et al. Knickpoint Evolution on the Yarlung River: Evidence for late Cenozoic Uplift of the Southeastern Tibetan Plateau Margin

In our knickpoint celerity model, the time at which the three modeled tributaries experienced a base

284 level fall is assumed to be roughly 4.4 Ma $(t)$. This is based on the closest apatite ${ }^{4} \mathrm{He} /{ }^{3} \mathrm{He}$ sample affected 285 by knickpoint migration (sample ML01). In this model, the Jiacha knickpoint projects to the upstream 286 edge of the Namche Barwa massif at 10 Ma. Solutions to the knickpoint celerity model are linear, 287 meaning that a doubling of the assumed initiation time for the tributary knickpoints to 8.8 Ma relocates 288 the Jiacha knickpoint to this point at $\sim 20 \mathrm{Ma}$. We find that scenarios where $t$ is far less than $4.4 \mathrm{Ma}$ 289 predict past locations that are inconsistent with our ${ }^{4} \mathrm{He} /{ }^{3} \mathrm{He}$ apatite data. Apatite (U-Th)/He ages of 7-12 290 Ma downstream of our sample locations (Zeitler et al., 2014) are also consistent with propagation of the 291 Jiacha knickpoint over $\sim 10$ Ma.

292 Knickpoint retreat rates derived from our interpretation of ${ }^{4} \mathrm{He} /{ }^{3} \mathrm{He}$ apatite spectra and (U-Th)/He ages 293 are $20-25 \mathrm{~km} / \mathrm{Ma}$. Our celerity modeling results suggest rates of $\sim 40 \mathrm{~km} / \mathrm{Ma}$, whereas the best-fitting 294 Pecube result was modeled with a retreat rate of $30 \mathrm{~km} / \mathrm{Ma}$. Although there is a degree of dependence of 295 the celerity modeling on the apatite data, given the uncertainty in these analyses, the rates calculated 296 among the different methods do not vastly differ and highlight the consistency of our model

297 predictions. The discrepancy between retreat rates predicted from the thermokinematic and celerity 298 modeling are likely due to the simplified nature of this version of Pecube, which does not include a full 299 landscape evolution model.

300 The bestfitting of theexplored Pecube model predicts ages for the three samples farthest downstream 301 that are slightly too young when compared to our observed data. This may result from these samples 302 having been collected from valley-wall locations that do not accurately represent paleo-river level. Wang 303 et al. (2014) demonstrated that the bedrock river valley is buried beneath 500 $\mathrm{m}$ of sediment in this 304 portion of the Yarlung. Samples collected from $500 \mathrm{~m}$ above river level would produce ages that were 305 slightly too old for our given model assumptions.

306 Collectively, the results presented here demonstrate that the knickpoints at $\sim 3500 \mathrm{~m}$ are present 307 throughout the present-day Yarlung River drainage network and that a wave of incision migrated 308 westward upstream from the western border of the Namche Barwa massif.This indicates that the base 
Schmidt et al. Knickpoint Evolution on the Yarlung River: Evidence for late Cenozoic Uplift of the Southeastern Tibetan Plateau Margin

309 level fall that formed the Jiacha knickpoint occurred downstream along the present course of the Yarlung

310 River and that the Yarlung has flowed eastward along the Indus-Yarlung suture from Jiacha through the

311 Eastern Syntaxis since at least $\sim 10$ Ma. This interpretationand the findings of Lang and Huntington

312 (2014) contrast with the ideathat the Yarlung River flowed westward through the Himalaya-traversing

313 Subansiri River for any significant amount of time (Cina et al., 2009; Zhang et al., 2012).

314 Notwithstanding, short-duration glacial or landslide damming events on the Yarlung River (see Korup

315 and Montgomery, 2008; Montgomery et al., 2004) may have temporarily impeded eastward flow and

316 retreat of the knickpoint and forced intermittent trans-Himalayan routing.

317 Apatite (U-Th)/He and fission track ages from farther downstream near the Nyang confluence

318 decrease to 4-5 Ma and within the Yarlung gorge are <1 Ma (Seward and Burg, 2008; Zeitler et al., 2014).

319 Young apatites outside of the massif are likely affected by lateral heat flow, which advects isotherms

320 towards the surface (Zeitler et al., 2014); consequently any evidence of knickpoint migration directly

321 adjacent to the massif has been removed. Recent discussion regarding tectonic-erosional feedbacks in this

322 region suggests that incision of the Yarlung promotes rapid rock uplift in the massif that began at 8-10

323 Ma (Zeitler et al., 2014). As localized rapid exhumation progressed, the position of the large $\sim 2 \mathrm{~km}$

324 knickpoint within the Namche Barwa massif was fixed, holding upstream base level to $~ 3000 \mathrm{~m}$, which is

325 consistent with a slowing of upstream erosion rates after 5 Ma (Finnegan et al., 2008; Zeitler et al., 2014).

326 Our calculated retreat rates suggest the Jiacha knickpoint migrated out of the massif just prior to or

327 coincident with the initiation of rapid rock uplift. It is interesting to note this nearly synchronous series of

328 events and we speculate on a relationship between knickpoint migration and initiation of rapid rock uplift

329 in the syntaxis in Section 6.3. Our knickpoint migration model is consistent with recent measurement of an

$330 \sim 500 \mathrm{~m}$ thick sediment package within the Yarlung River downstream of the Jiacha knickpoint (Wang et

331 al. 2014) in that our apatite data and knickpoint celerity modeling require the river to occupy a deeply

332 incised canyon that formed over the last $\sim 10 \mathrm{Ma}$. Formation of the $\sim 2 \mathrm{~km}$ knickpoint within the Yarlung

333 gorge and backfilling of the Yarlung canyon however may have initiated anytime between 2.5 Ma (Wang

334 et al. 2014) and $\sim 10$ Ma. 
Schmidt et al. Knickpoint Evolution on the Yarlung River: Evidence for late Cenozoic Uplift of the Southeastern Tibetan Plateau Margin

\subsection{Implications forDrainage Evolution}

337 Barbed tributaries and wind gaps along the Parlung River indicate that it once flowed to the southeast 338 through the Lhuit and/or Irrawaddy Rivers, contrasting its present-day northwest flow direction (Fig. 3;

339 Burchfiel et al., 2000; Clark et al., 2004). Two end-member models for the reversal of the Parlung suggest

340 very different paleo-drainage patterns within the region and thus different sediment evacuation routes.

341 Some authors have postulated the existence of an antecedent Yarlung-Siang-Brahmaputra River, flowing

342 in its present configuration since at least the Early Miocene (Fig. 7a), with capture of a separate Yigong-

343 Parlung-Lhuit River occurring by northeastward migration of the deforming Namche Barwa antiform

344 (Hallet and Molnar, 2001; Lang and Huntington, 2014; Seward and Burg, 2008). Others suggest a paleo-

345 Yarlung-Parlung-Lhuit connection with headward cutting of the Siang-Brahmaputra capturing the Parlung

346 (Fig. 7b; Brookfield, 1998; Clark et al., 2004; Liang et al., 2008; Robinson et al., 2014).

347 Our results provide new perspective on the timing of these drainage integration models just east of the

348 Namche Barwa area. Long profiles and slope-area analysis of the Siang, Parlung, and Yigong rivers and

349 their tributaries highlight the presence of $\sim 3500$ m elevation knickpoints (Fig. 3) indicating that these

350 rivers have experienced the same base level fall as the Yarlung River. Based on these observations, we

351 constrain knickpoint migration pathways and the timing of previously proposed scenarios for river

352 reorganization consistent with the locations of knickpoints at $\sim 3500 \mathrm{~m}$ in the drainage network.

353 If integration of the Yarlung, Parlung, and Siang occurred after the Jiacha knickpoint reached the

354 upper Yarlung valley, both the Siang-Brahmaputra and the Parlung-Lhuit would have experienced this

355 base level fall independently as we find evidence for knickpoints at $\sim 3500 \mathrm{~m}$ elevation in both drainages.

356 In a model in which the Yarlung was connected to the Parlung-Lhuit prior to this integration, the Jiacha

357 knickpoint would have traveled up the Lhuit, through the Parlung, and into the upper Yarlung

358 valley.However, we find evidence of an $~ 3500$ m elevation knickpoint in the Parlung longitudinal profile

359 presently located upstream of tributaries also containing knickpoints at $\sim 3500$ m elevation, indicating the

360 Parlung knickpoint propagated from the northwest. If it had migrated from the southeast, we would not 
Schmidt et al. Knickpoint Evolution on the Yarlung River: Evidence for late Cenozoic Uplift of the Southeastern Tibetan Plateau Margin

361 expect to find $\sim 3500$ m elevation knickpoints on tributaries that meet the Parlung northwest of the present 362 day Parlung knickpoint (Fig. 3). This suggests that the Parlung has flowed in its present northwesterly 363 course since at least $\sim 10 \mathrm{Ma}$, which is inconsistent with a post-10 Maintegration scenario.In an antecedent

364 Yarlung-Siang-Brahmaputra model, the Jiacha knickpoint would have originated on the Siang or

365 Brahmaputra portion of the drainage. The $\sim 3500$ m elevation knickpoints on the tributaries of the Parlung

366 and Yigong would therefore be the result of the same base level fall but would have originated on the

367 Lhuit rather than the Siang or Brahmaputra. An early connection between the Yarlung and Siang-

368 Brahmaputra is consistent with Gangdese detritus in Miocene foreland units (Cina et al., 2009; Lang and

369 Huntington, 2014). However, the location of the Parlung knickpoint is again inconsistent with migration

370 from the Lhuit.

371 We note that the Lhuit does not contain a major knickpoint at $\sim 3500 \mathrm{~m}$ and acknowledge that after

372 Jiacha knickpoint migration, localized uplift of the Parlung-Lhuit wind gap could have obscured evidence

373 of it. This would suggest that the Parlung knickpoint did not result from the base level fall discussed in

374 this paper, but rather represents a later knickpoint that was subsequently uplifted to $\sim 3500 \mathrm{~m}$. However,

375 we are presently unaware of any evidence for such localized uplift in this region.

376 If integration of the Yarlung, Parlung, and Siang rivers occurred prior to $\sim 10 \mathrm{Ma}$, the Jiacha

377 knickpoint would have originated from within the Siang or Brahmaputra portion of the drainage (Fig. 7a,

378 b). This is consistent with knickpoints at $~ 3500$ m elevation present within tributaries of the Siang, close

379 to its confluence with the Yarlung. Gangdese Batholith-derived detritus present within Early through Late

380 Miocene units of the Himalayan foreland basin is also consistent with pre-Late Miocene connection of the

381 Yarlung and Siang-Brahmaputra (Chirouze et al., 2013; Cina et al., 2009; Lang and Huntington, 2014).

382 Moreover, evidence of fish species diversification at 19-24 Ma (Britz, 2009; Ruber et al., 2004) and an

383 increase in sediment flux into the Bengal Basin in the Eocene to Early Miocene (Alam et al., 2003)

384 indicate an early capture event as suggested by Robinson et al. (2014).

385 Because knickpointsat $\sim 3500$ m elevation exist on both the Parlung and Yigong rivers and evidence of 386 uplift in the Parlung-Lhuit windgap is lacking, theseknickpointslikelymigrated up the Parlung and Yigong 
Schmidt et al. Knickpoint Evolution on the Yarlung River: Evidence for late Cenozoic Uplift of the Southeastern Tibetan Plateau Margin

via the Siang. This requires that the Yarlung, Yigong, Parlung, and Siang were integrated at the time of headward migration through the Namche Barwa region. In this case, either pre-integration drainage configuration previously proposed is consistent with the mapped knickpoint locations, as long as integration occurred prior to $\sim 10 \mathrm{Ma}$ (Fig. 7).

\subsection{Origin of 3500 m elevation Knickpoint}

From our knickpoint mapping, we infer that a major base level fall occurred downstream of the

394 Yarlung-Siang confluence that caused knickpoint formation and generated a wave of incision that

395 propagated upstream as previously suggested by Zeitler et al. (2014). We find evidence of this base level

396 fall in knickpoints in tributaries on the Siang downstream until the maximum elevations of its tributaries

397 do not reach $3500 \mathrm{~m}$. Below this point, the tributaries may have experienced a base level fall, but the

398 stream has fully adjusted to the new base level, precluding preservation and observation of a knickpoint.

399 A base level fall could be the result of a drainage capture event, deformation or uplift, or an abrupt

400 change in precipitation. However, knickpoints at $\sim 3500 \mathrm{~m}$ elevationare evident on other major rivers on

401 the eastern margin of the Tibetan plateau including the Irrawaddy, Salween, Mekong, Yangtze, and

402 Yalong (Fig. S1). Harkins et al. (2007) also describe a knickpoint at 3500 m elevation on the Yellow

403 river and several of its tributaries. Given the elevation change at the Jiacha knickpoint is $500 \mathrm{~m}$, and that

404 we find knickpoints of its approximate elevation throughout the eastern Tibetan plateau, we speculate that

405 these knickpoints resulted from uplift of at least $500 \mathrm{~m}$ of the entire eastern margin just prior to $\sim 10 \mathrm{Ma}$.

406 Clark et al. (2005) and Duvall et al. (2012) describe a similar wave of incision at 9-13 Ma constrained by

407 apatite (U-Th)/He thermochronology in the three-rivers region and elsewhere on the eastern margin of

408 Tibet, which they relate to eastward expansion of the plateau. Additional knickpoint celerity modeling

409 and thermochronologic constraints on the rivers of eastern Tibet are required to address the scale and

410 potential synchronicity of this base level change.

411 Localized rapid rock uplift within the Namche Barwa massif pinned an $\sim 2 \mathrm{~km}$ knickpoint to this

412 location (Zeitler et al. 2001, Koons et al. 2013). As our celerity modeling suggests, the Jiacha knickpoint 
Schmidt et al. Knickpoint Evolution on the Yarlung River: Evidence for late Cenozoic Uplift of the Southeastern Tibetan Plateau Margin

413 migrated out of this region at $~ 10 \mathrm{Ma}$, concurrent with or just prior to development of rapid rock uplift

414 (Zeitler et al. 2014). The Jiacha and Namche Barwa knickpoints may haveoriginated as a single feature

415 resulting from a base level fall and were segmented with pinning of the Namche Barwa knickpoint. A 500

416 m elevation change (i.e. the Jiacha knickpoint) continued to migrate upstream to its present position. If

417 resulting from the uplift of the southeastern margin of Tibet just prior to $10 \mathrm{Ma}$, thefull magnitude of

418 this base level fall may have been the combined elevation change of these two features.Total uplift of the

419 margin could therefore be upwards of $2.5 \mathrm{~km}$.

\section{Conclusions}

422 We present thermochronology, knickpoint celerity modeling, and thermokinematic modeling from

423 southeastern Tibetthat demonstrates the mechanism and timing of incision of the Yarlung River. A series

424 of $\sim 3500$ m elevation knickpoints existsthroughout the region andslope-area and $\chi$ analysis of several

425 longitudinal profiles from the drainage basin confirms their genetic relationship,suggesting a wave of

426 knickpoint migration incised the Yarlung canyon. ${ }^{4} \mathrm{He} /{ }^{3} \mathrm{He}$ apatite thermochronology data from transect

427 along the Yarlung are consistent with a wave of incision propagating upstream towards the Jiacha

428 knickpoint. Celerity modeling projects the Jiacha knickpoint to just upstream of the Namche Barwa

429 massif at $\sim 10 \mathrm{Ma}$. Thermokinematic modeling of a simplified Jiacha knickpoint incision scenario predicts

430 apatite (U-Th)/He ages similar to our observed data.

431 The spatial arrangement of multiple knickpoints at $\sim 3500$ m elevation in this region indicates that

432 previously-recognized reorganization of the major rivers in the drainage just east of the Namche Barwa

433 massif occurred prior to $\sim 10 \mathrm{Ma}$ and that the Yarlung flowed predominantly eastward since at least this

434 time. Our results suggest a major base level fall resulting from uplift of 500-2500 m of the southeastern

435 Tibetan margin occurred just prior to $10 \mathrm{Ma}$.

436

437 Acknowledgements 
Schmidt et al. Knickpoint Evolution on the Yarlung River: Evidence for late Cenozoic Uplift of the Southeastern Tibetan Plateau Margin

This work was supported by an NSF Continental Dynamics program grant (EAR-1111853) to P.K.Z. and D.L.S. and a Geological Society of America Graduate Student Research Grant to J.L.S. We thank

440 FanyiMeng, Jin Yue, and Yue Chen for collecting and sharing samples and Zhidan Zhao, Mo Xuanxue, 441 and Di-Cheng Zhu for help with field logistics.

\section{References}

444 Alam, M., Alam, M. M., Curray, J. R., Chowdhury, M. L. R., Gani, M. R., 2003.An overview of the sedimentary geology of the Bengal Basin in relation to the regional tectonic framework and basin-fill history. Sedimentary Geology. 155, 179-208.

Berlin, M. M. and Anderson, R. S., 2007. Modeling of knickpoint retreat on the Roan Plateau, western Colorado. Journal of Geophysical Research.112, F03S06.

Braun, J., 2003. Pecube; a new finite-element code to solve the 3D heat transport equation including the effects of a time-varying, finite amplitude surface topography.Computers \& Geosciences.29, 787794.

Braun, J., 2002. Quantifying the effect of Recent relief changes on age-elevation relationships. Earth and Planetary Science Letters. 200, 331-343.

Britz, R., 2009.Danionellapriapus, a new species of miniature cyprinid fish from West Bengal, India (Teleostei: Cypriniformes: Cyprinidae). Zootaxa. 53-60.

Brookfield, M., 2008. Evolution of the great river systems of southern Asia during the Cenozoic IndiaAsia collision: Rivers draining north from the Pamir syntaxis. Geomorphology. 100, 296-311. 
Schmidt et al. Knickpoint Evolution on the Yarlung River: Evidence for late Cenozoic Uplift of the Southeastern Tibetan Plateau Margin

Burchfiel, B. C., Clark, M., Wang, E., Chen, Z., Liu, Y., Pan, G., 2000.Tectonic framework of the Namche Barwa region, Eastern Himalayan Syntaxis, SE Tibet.Abstracts with Programs Geological Society of America.32, 33.

Chirouze, F., Huyghe, P., van der Beek, P., Chauvel, C., Chakraborty, T., Dupont-Nivet, G., Bernet, M., 2013. Tectonics, exhumation, and drainage evolution of the eastern Himalaya since 13 Ma from detrital geochemistry and thermochronology, Kameng River section, Arunachal Pradesh.Geological Society of America Bulletin.125, 523-538.

Cina, S., Yin, A., Grove, M., Dubey, C., Shukla, D., Lovera, O., Kelty, T., Gehrels, G., Foster, D., 2009. Gangdese arc detritus within the eastern Himalayan Neogene foreland basin: Implications for the Neogene evolution of the Yalu-Brahmaputra River system. Earth and Planetary Science Letters. $285,150-162$.

Clark, M. K., House, M. A., Royden, L. H., Whipple, K. X., Burchfiel, B. C., Zhang, X., Tang, W., 2005. Late Cenozoic uplift of southeastern Tibet.Geology (Boulder).33, 525-528.

Clark, M. K., Schoenbohm, L. M., Royden, L. H., Whipple, K. X., Burchfiel, B. C., Zhang, X., Tang, W., Wang, E., Chen, L., 2004. Surface uplift, tectonics, and erosion of eastern Tibet from large-scale drainage patterns. Tectonics. 23, 20.

Crosby, B. T. and Whipple, K. X., 2006. Knickpoint initiation and distribution within fluvial networks; 236 waterfalls in the Waipaoa River, North Island, New Zealand. Geomorphology. 82, 16-38.

Duvall, A. R., Clark, M. K., Avdeev, B., Farley, K. A., Chen, Z., 2012. Widespread late Cenozoic increase in erosion rates across the interior of eastern Tibet constrained by detrital low temperature thermochronometry. Tectonics. 31, Citation TC3014. 
Schmidt et al. Knickpoint Evolution on the Yarlung River: Evidence for late Cenozoic Uplift of the Southeastern Tibetan Plateau Margin

479 Finnegan, N. J., Hallet, B., Montgomery, D. R., Zeitler, P. K., Stone, J. O., Anders, A. M., Liu Yuping, 2008. Coupling of rock uplift and river incision in the Namche Barwa-Gyala Peri Massif, Tibet. Geological Society of America Bulletin.120, 142-155.

Flowers, R. M., Ketcham, R. A., Shuster, D. L., Farley, K. A., 2009. Apatite (U-Th)/He thermochronometry using a radiation damage accumulation and annealing model.GeochimicaEtCosmochimicaActa. 73, 2347-2365.

Goren, L., Fox, M., Willett, S. D., 2014.Tectonics from fluvial topography using formal linear inversion; theory and applications to the Inyo Mountains, California. Journal of Geophysical Research: Earth Surface. 119, 1651-1681.

Hack, J. T., 1957. Studies of longitudinal stream profiles in Virginia and Maryland. U.S.Geological Survey Professional Paper. 45-97.

Hallet, B. and Molnar, P., 2001. Distorted drainage basins as markers of crustal strain east of the Himalaya. Journal of Geophysical Research.106, 13-13,709. headwaters of the Yellow River, northeastern Tibet, China.Journal of Geophysical Research.112,

Howard, A. D., 1994. A detachment-limited model of drainage basin evolution.Water Resources Research.30, 2261-2285. Bulletin.94, 739-752. 
Schmidt et al. Knickpoint Evolution on the Yarlung River: Evidence for late Cenozoic Uplift of the Southeastern Tibetan Plateau Margin

Kapp, P., Taylor, M., Stockli, D., Ding, L., 2008. Development of active low-angle normal fault systems during orogenic collapse; insight from Tibet.Geology (Boulder).36, 7-10.

Ketcham, R. A., 2005. Forward and inverse modeling of low-temperature thermochronometry data.Reviews in Mineralogy and Geochemistry.58, 275-314.

Kirby, E. and Whipple, K., 2001. Quantifying differential rock-uplift rates via stream profile analysis. Geology (Boulder).29, 415-418.

Koons, P.O., Zeitler, P.K., and Hallet, B., 2013, Tectonic Aneurysms and Mountain Building, in Schroder, J. and Owen, L.A. eds., Treatise on Geomorphology, Academic Press, San Diego, p. 318-349.

Korup, O. and Montgomery, D. R., 2008. Tibetan plateau river incision inhibited by glacial stabilization of the Tsangpo gorge. Nature. 455, 786-789.

Lang, K. A. and Huntington, K. W., 2014. Antecedence of the Yarlung-Siang-Brahmaputra River, eastern Himalaya. Earth and Planetary Science Letters. 397, 145-158.

Liang, Y., Chung, S., Liu, D., Xu, Y., Wu, F., Yang, J., Wang, Y., Lo, C., 2008.Detrital zircon evidence from Burma for reorganization of the eastern Himalayan river system.American Journal of Science.308, 618-638. on cooling histories during erosion.Tectonophysics. 270, 167-195.

517 Montgomery, D. R., Hallet, B., Liu, Y., Finnegan, N., Anders, A., Gillespie, A., Greenberg, H. M., 2004. Evidence for Holocene megafloods down the Tsangpo River gorge, southeastern Tibet. Quaternary Research. 62, 201-207. 
Schmidt et al. Knickpoint Evolution on the Yarlung River: Evidence for late Cenozoic Uplift of the Southeastern Tibetan Plateau Margin

520 Niemann, J. D., Gasparini, N. M., Tucker, G. E., Bras, R. L., 2001. A quantitative evaluation of Playfair's 521 law and its use in testing long-term stream erosion models. Earth Surface Processes and $522 \quad$ Landforms. 26, 1317-1332.

Perron, J. T. and Royden, L., 2013. An integral approach to bedrock river profile analysis. Earth Surface Processes and Landforms. 38, 570-576.

Pritchard, D., Roberts, G. G., White, N. J., Richardson, C. N., 2009. Uplift histories from river profiles. Geophysical Research Letters. 36.

Robinson, R. A. J., Brezina, C. A., Parrish, R. R., Horstwood, M. S. A., Oo, N. W., Bird, M. I., Thein, M., Walters, A. S., Oliver, G. J. H., Zaw, K., 2014. Large rivers and orogens; the evolution of the Yarlung Tsangpo-Irrawaddy system and the eastern Himalayan syntaxis.Gondwana Research. 26,

Rosenbloom, N. A. and Anderson, R. S., 1994. Hillslope and channel evolution in a marine terraced landscape, Santa Cruz, California. Journal of Geophysical Research.99, 13-14,029.

Royden, L. and Taylor Perron, J., 2013. Solutions of the stream power equation and application to the

Rüber, L., Britz, R., Kullander, S. O., Zardoya, R., 2004. Evolutionary and biogeographic patterns of the Badidae (Teleostei: Perciformes) inferred from mitochondrial and nuclear DNA sequence data. Molecular Phylogenetics and Evolution. 32, 1010-1022. 293, 377-387. 
Schmidt et al. Knickpoint Evolution on the Yarlung River: Evidence for late Cenozoic Uplift of the Southeastern Tibetan Plateau Margin

542 Seward, D. and Burg, J. P., 2008. Growth of the Namche Barwa Syntaxis and associated evolution of the Tsangpo Gorge; constraints from structural and thermochronological data.Tectonophysics. 451,

Shuster, D. L., Cuffey, K. M., Sanders, J. W., Balco, G., 2011. Thermochronometry reveals headward propagation of erosion in an alpine landscape. Science. 332, 84-88.

Shuster, D. L., Flowers, R. M., Farley, K. A., 2006. The influence of natural radiation damage on helium diffusion kinetics in apatite. Earth and Planetary Science Letters. 249, 148-161.

Shuster, D. L., Farley, K. A., Sisterson, J. M., Burnett, D. S., 2004. Quantifying the diffusion kinetics and

Snyder, N. P., Whipple, K. X., Tucker, G. E., Merritts, D. J., 2000. Landscape response to tectonic forcing; digital elevation model analysis of stream profiles in the Mendocino triple junction region, Northern California. Geological Society of America Bulletin.112, 1250-1263.

van der Beek, P. and Bishop, P., 2003. Cenozoic river profile development in the upper Lachlan catchment (SE Australia) as a test of quantitative fluvial incision models.Journal of Geophysical

Wang, P., Scherler, D., Liu-Zeng, J., Mey, J., Avouac, J., Zhang, Y., Shi, D., 2014. Tectonic control of Research. 108, . 107, 189-206. 
Schmidt et al. Knickpoint Evolution on the Yarlung River: Evidence for late Cenozoic Uplift of the Southeastern Tibetan Plateau Margin

563 Whipple, K. X., Hancock, G. S., Anderson, R. S., 2000. River incision into bedrock; mechanics and 564 relative efficacy of plucking, abrasion, and cavitation.Geological Society of America $565 \quad$ Bulletin.112, 490-503.

566 Whipple, K. X. and Tucker, G. E., 1999. Dynamics of the stream-power river incision model; implications for height limits of mountain ranges, landscape response timescales, and research needs.Journal of Geophysical Research.104, 17-17,674.

Yin, A., Kapp, P. A., Murphy, M. A., Manning, C. E., Harrison, T. M., Grove, M., Ding, L., Deng, X.,

Yin, A., Dubey, C.S., Kelty, T.K., Webb, A.A.G., Harrison, T.M., Chou, C.Y. and Célérier, J., Wu, C., 1999. Significant late Neogene east-west extension in northern Tibet.Geology (Boulder).27, 787-790. Black Hills and northern High Plains; a different perspective on the late Cenozoic exhumation of the Laramide Rocky Mountains.Geology (Boulder).29, 547-550. topographic evolution of Namche Barwa and the easternmost Lhasa Block, Tibet.Special Paper Geological Society of America.507, 23-58. 
Schmidt et al. Knickpoint Evolution on the Yarlung River: Evidence for late Cenozoic Uplift of the Southeastern Tibetan Plateau Margin

Zhang, D. D., 1998. Geomorphological problems of the middle reaches of the Tsangpo River, Tibet. Earth Surface Processes and Landforms. 23, 889-903.

Zhang, J., Yin, A., Liu, W. C., Wu, F. Y., Lin, D., Grove, M., 2012. Coupled U-Pb dating and Hf isotopic analysis of detrital zircon of modern river sand from the Yalu River (Yarlung Tsangpo) drainage system in southern Tibet; constraints on the transport processes and evolution of Himalayan rivers. Geological Society of America Bulletin.124, 1449-1473.

Figure 1. Overview map of the Yarlung River drainage basin (location highlighted in inset). The drainage

594 area includes a significant portion of southern Tibet. Major rifts (from Kapp and Guynn 2004) locally

595 coincide with knickpoints along the river. The Nari Yun Chu Rift coincides with the Yarlung River at the

596 Jiacha knickpoint (highlighted in red). Dashed ellipse illustrates approximate area of rapid rock uplift in 597 the Namche Barwa massif (adapted from Stewart et al. 2008).

599 Figure 2. A) Elevation, drainage area, and SL index plotted against river distance for the Yarlung River.

600 B) Slope-area plot for Yarlung River. Filled circles denote knickpoint reaches. Both A and B highlight the 601 magnitude of the Jiacha (in red) and other knickpoints on the Yarlung River.

602

603 Figure 3. Analyzed tributaries (black, red, and green) and major rivers (blue) of southeastern Tibet

604 (location highlighted in Figure 1). Circles indicate locations of identified knickpoints at $\sim 3500 \mathrm{~m}$

605 elevation. Black circles indicate reaches with convex profiles that are not associated with fluvial

606 knickpoints (see Section 2). Tributaries used in knickpoint celerity modeling are highlighted in red. Green 
Schmidt et al. Knickpoint Evolution on the Yarlung River: Evidence for late Cenozoic Uplift of the Southeastern Tibetan Plateau Margin

607 tributary has undergone a recent capture event as discussed in Section 2 and Figure 4b. Green star

608 indicates the projected Jiacha knickpoint location at $\sim 10 \mathrm{Ma}$, based on our knickpoint celerity model.

610 Figure 4. A) Knickpoint distance plotted against tributary drainage area for Yarlung tributaries containing

611 knickpoints at $\sim 3500$ m elevation. Each knickpoint is plotted as filled circle. Note: Nyang river

612 knickpoint located out of plot range. B) $\chi$-elevation plot for tributaries on the north (top) and south

613 (bottom) side of the Yarlung containing knickpoints at $\sim 3500 \mathrm{~m}$ (red circles). We assume a concavity of

614 0.5. South tributary shaded in green (see Figure 3 for location) displays clear offset in $\chi$, resulting from

615 recent river capture as discussed in Section 2.

616

617 Figure 5. Sample ages and ${ }^{4} \mathrm{He} /{ }^{3} \mathrm{He}$ results. A) Map showing sample locations (yellow circles) and

618 corresponding (U-Th)/He apatite age. The Jiacha knickpoint is highlighted in red. Samples located at the

619 base of the Jiacha knickpoint are labeled with mean age of all aliquots (shown with 1 standard deviation

620 uncertainty), whereas downstream transect samples are calculated from individual aliquot in shown in B.

621 B) Modeled ${ }^{4} \mathrm{He} /{ }^{3} \mathrm{He}$ time-temperature (right panel) and ratio evolution spectra (left panel) results. Ratios

622 of ${ }^{4} \mathrm{He} /{ }^{3} \mathrm{He}$ for each step relative to the bulk ${ }^{4} \mathrm{He} /{ }^{3} \mathrm{He}$ of a sample are plotted against the cumulative ${ }^{3} \mathrm{He}$

623 release fraction $\left(\sum^{3} \mathrm{He}\right.$; black boxes). Gray paths represent modeled cooling histories that do not predict

624 the sample (U-Th)/He age to within the observed variance between analyzed crystals. Green paths are

625 those that predict the (U-Th)/He age and have good fits to the observed spectra for that sample. Yellow

626 and red paths also predict the age but have progressively worse fits. Black paths are the best fitting of the

627 explored Pecube models.

628

629 Figure 6. Apatite (U-Th)/He data from this study plotted with approximate distance from the lip of the

630 Jiacha knickpoint. Open circles are (U-Th)/He age predicted from HeFTy using thermal histories of

631 corresponding sample nodes extracted from the best fitting of the explored Pecube models (see Section 5).

632 Black circles are our observed ${ }^{4} \mathrm{He} /{ }^{3} \mathrm{He}$ sample ages from aliquots in Figure 5 with estimated 10\% 
Schmidt et al. Knickpoint Evolution on the Yarlung River: Evidence for late Cenozoic Uplift of the Southeastern Tibetan Plateau Margin

633 uncertainty in age. Black triangles are our observed average (U-Th)/He ages with standard deviation for

634 samples from the base of the knickpoint. Gray circles are apatite (U-Th)/He data from Zeitler et al. (2014)

635 and were not included in Pecube model. Approximate sediment depth in Yarlung canyon estimated from

636 Wang et al. (2014).

637

638 Figure 7. Schematic temporal progression of Yarlung-Parlung-Siang integration scenarios consistent with

639 present day knickpoint locations. Unlabeled tributaries are those analyzed here that contain knickpoints

640 at $3500 \mathrm{~m}$. Black circles are locations of $\sim 3500 \mathrm{~m}$ elevation knickpoints on major rivers of the region.

641 Black arrows depict flow directions. Panels A, C, and D demonstrate an antecedent Yarlung-Siang

642 drainage captures the Parlung prior to migration of the Jiacha knickpoint from the Siang. Panels B, C, and

643 D show a similar scenario with a Yarlung-Parlung drainage prior to its capture by a headward-cutting

644 Siang. Regardless of pre-integration configuration, integration by $\sim 10 \mathrm{Ma}$ is required to account for

645 Parlung and tributary knickpoints. 
Figure 1

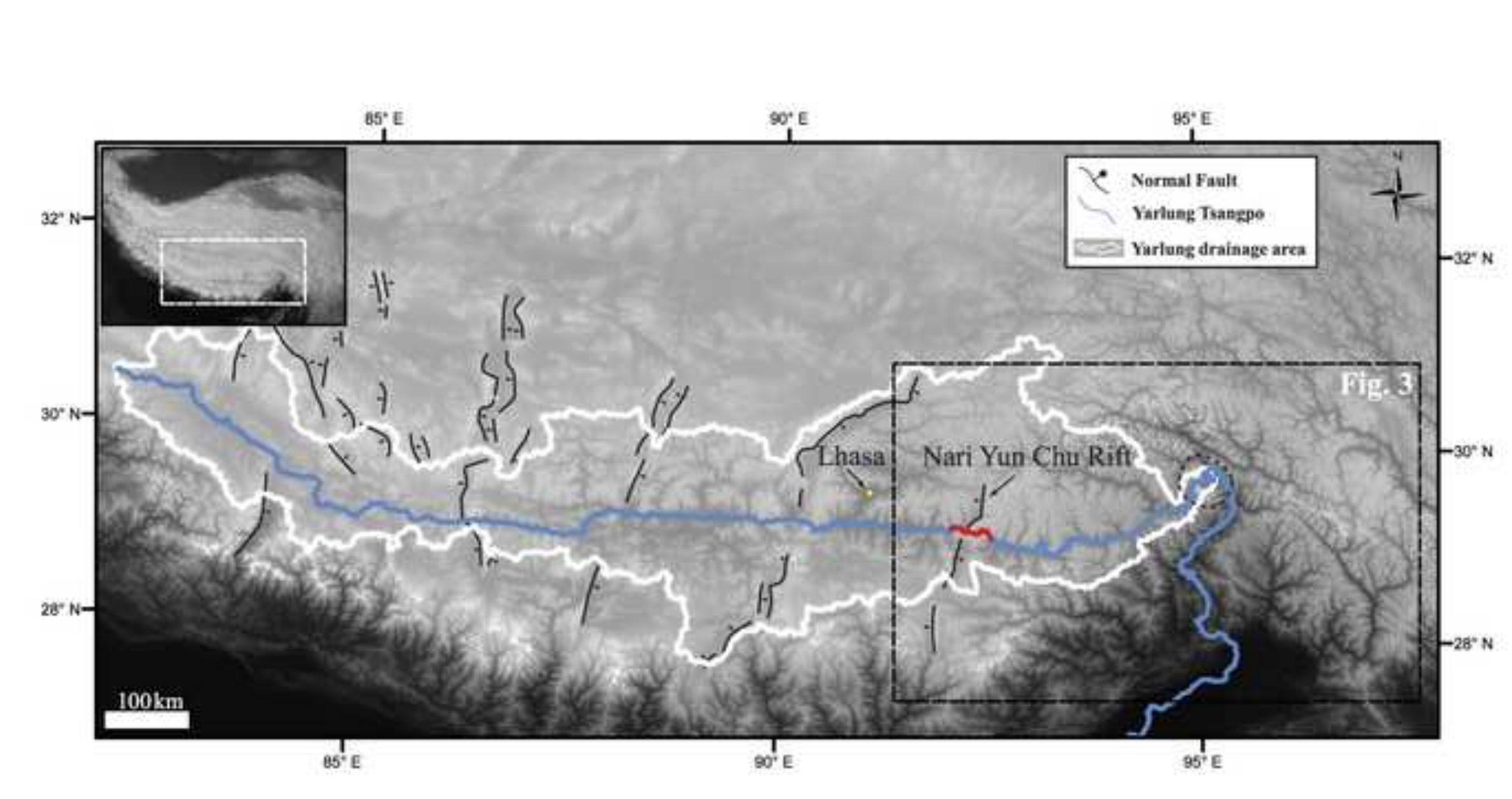

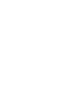


Figure 2
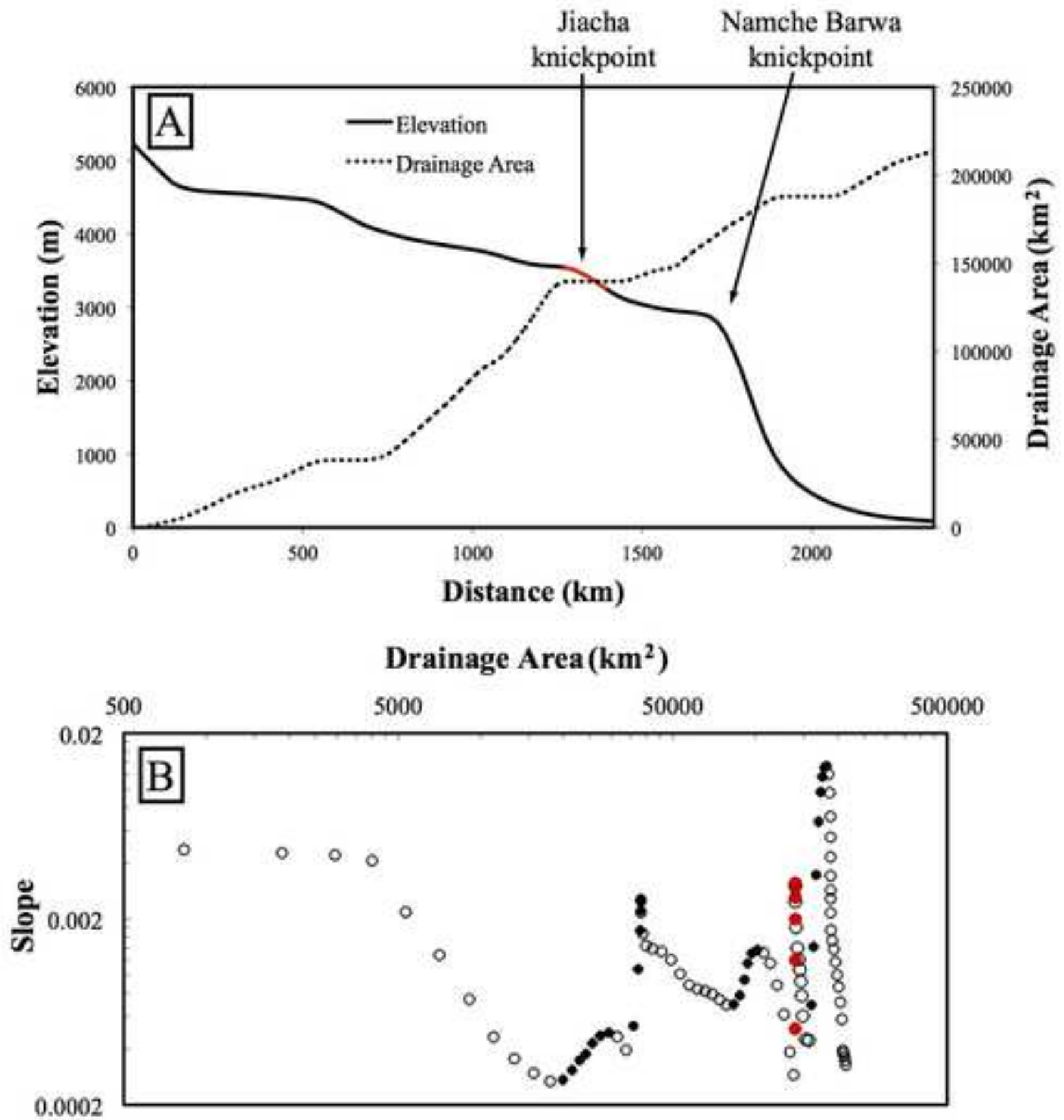


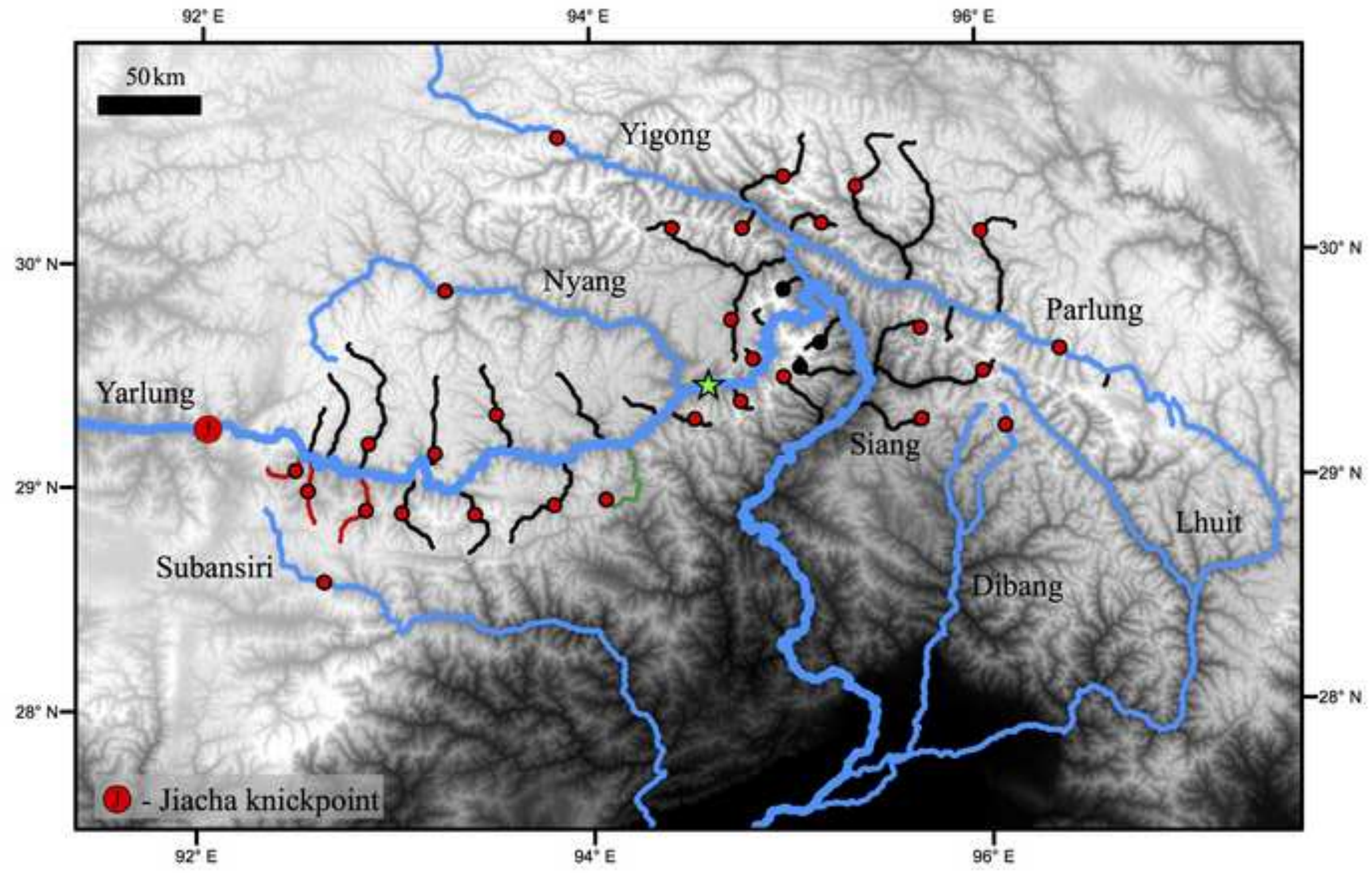



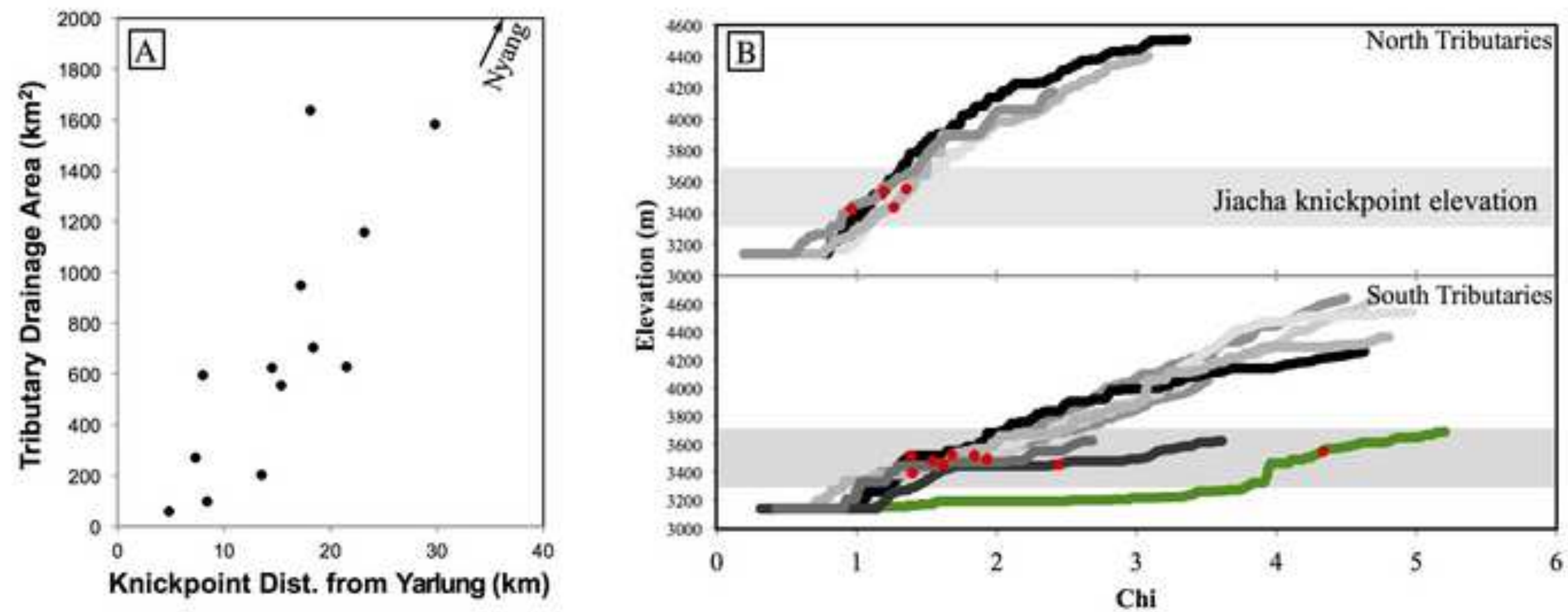
Figure 5
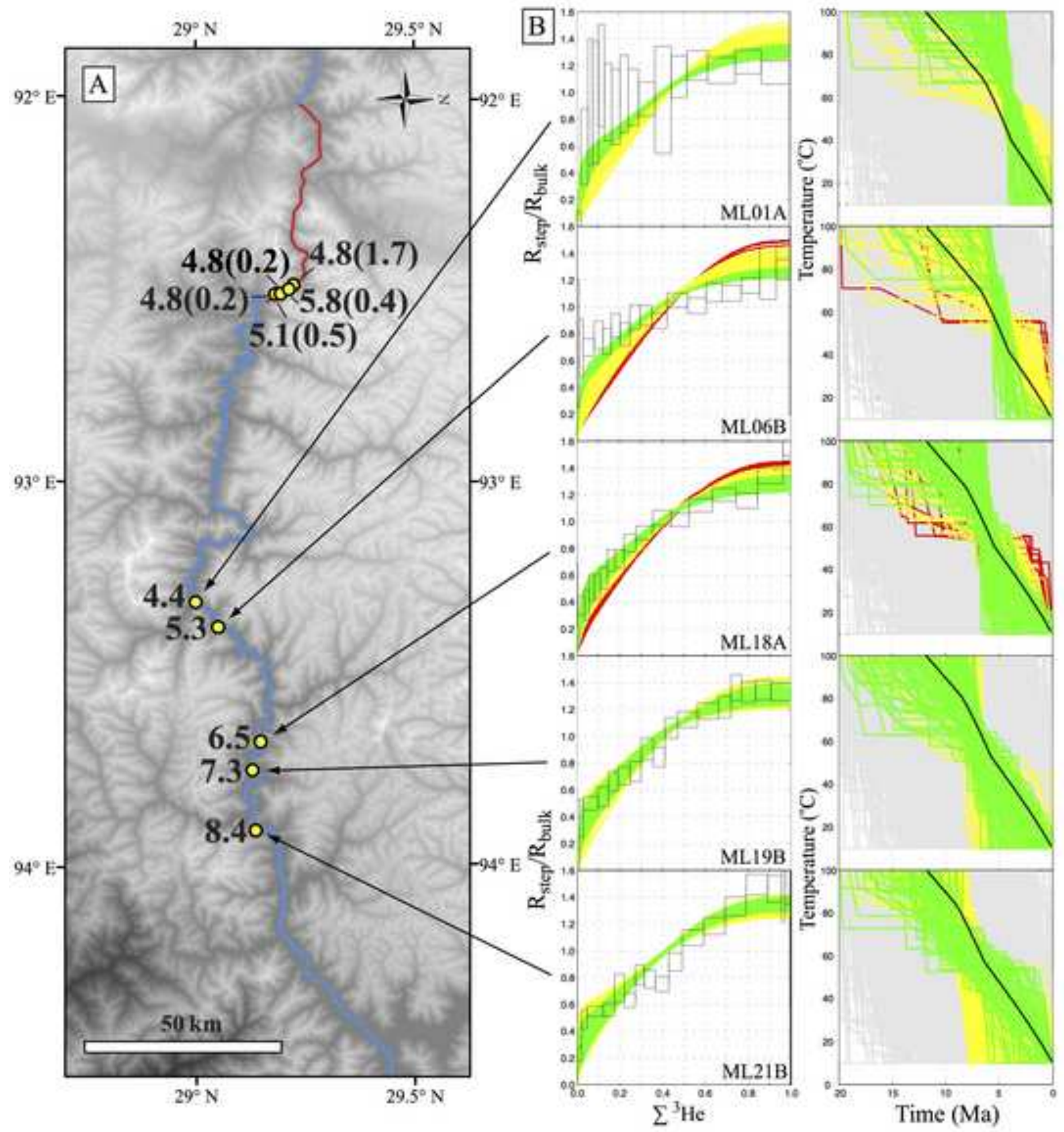


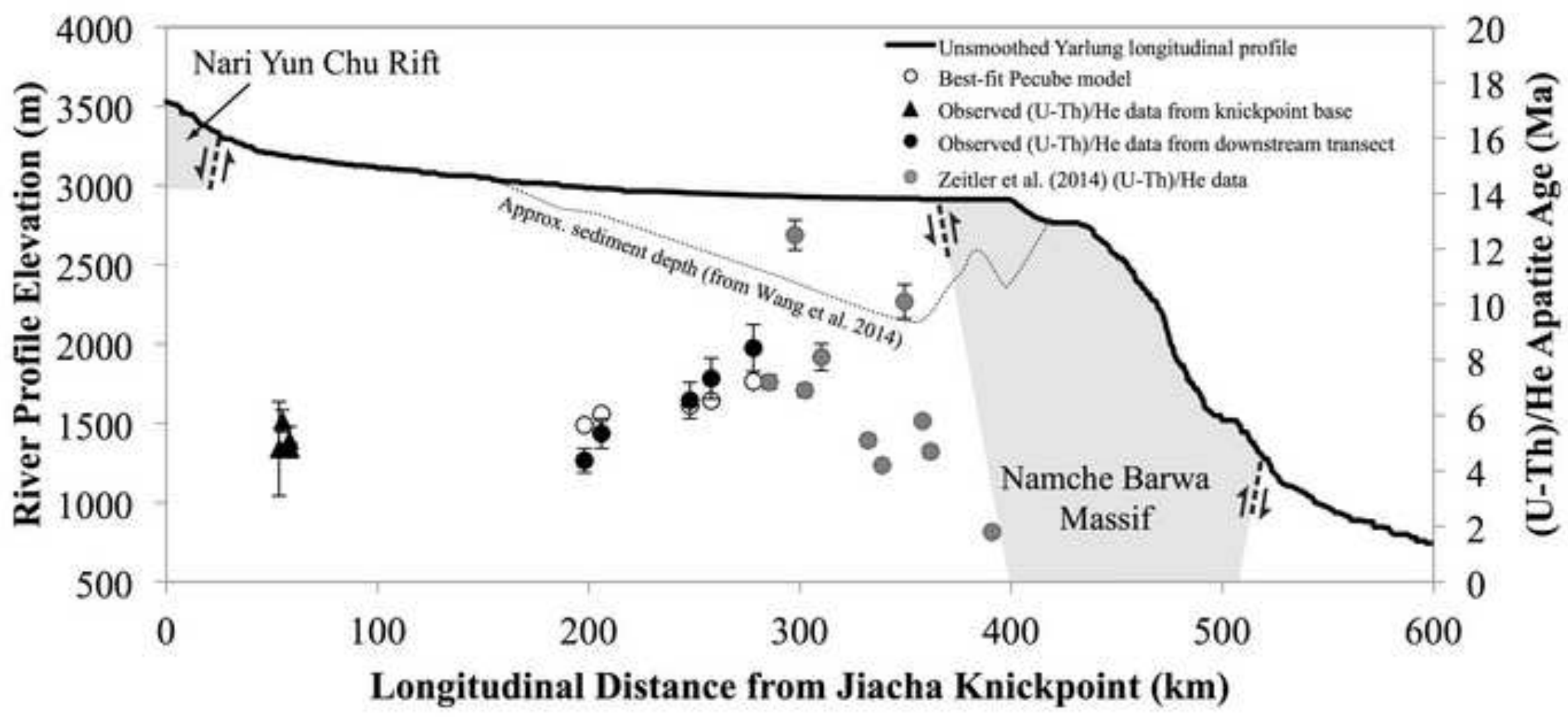




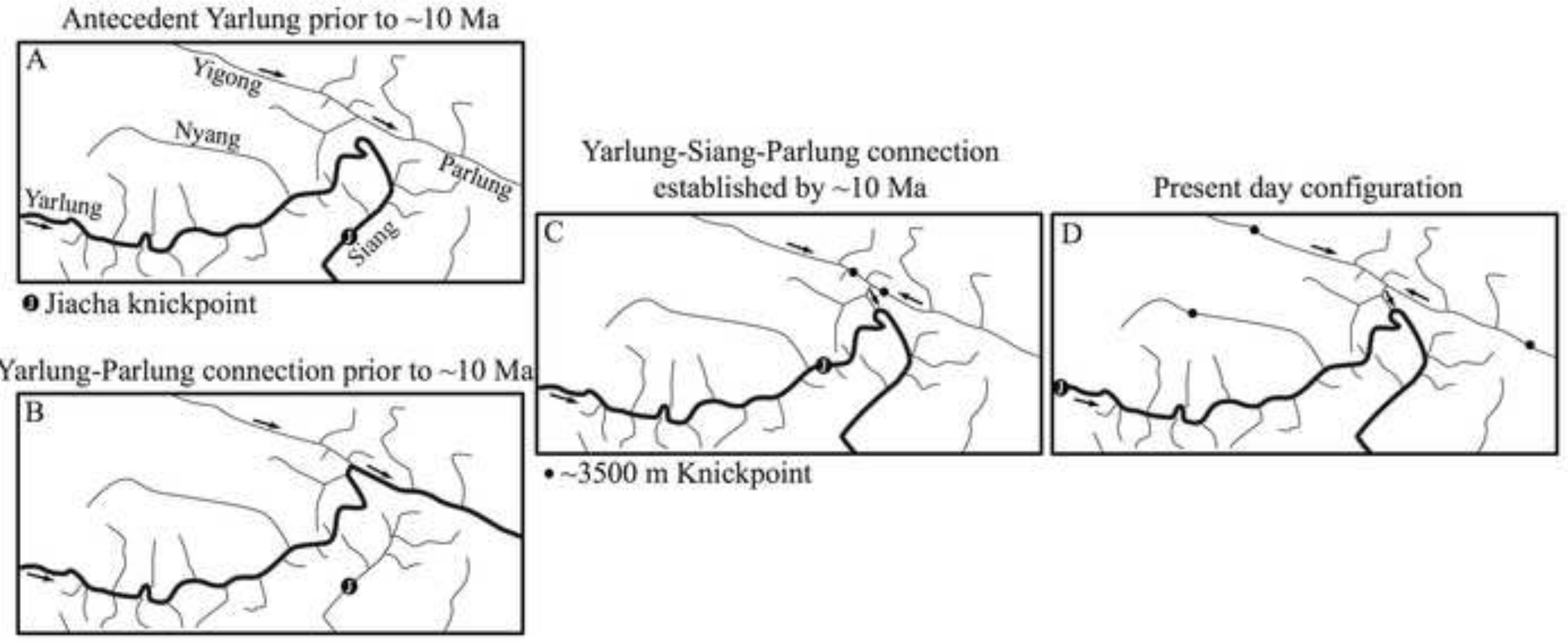

